\title{
Correspondence
}

Psychological Medicine, 39 (2008).

doi:10.1017/S0033291708004571

First published online 10 October 2008

\section{Letter to the Editor}

\section{Auditory-verbal hallucinations and ordinary verbal thought}

While the discussion concerning advantages and disadvantages of the single-symptom approach compared to other approaches, such as the syndrome/ diagnosis approach, is far from resolved*, I agree with Mojtabai \& Reider's (1998) conclusion that each approach has different aims and answers different questions and therefore, in my opinion, can be viewed as complementary. In the spirit of methodological pluralism - both approaches deserve to be, as it were, in each researcher's 'toolbox'.

In particular, hallucinations have frequently been examined within a single-symptom approach (for a review see Aleman \& Larøi, 2008) $\dagger$. There has, furthermore, been a noteworthy recent interest in a 'phenomenological' approach $\$$, both within psychopathology research in general (cf. Owen \& Harland, 2007) and for hallucinations in particular (cf. Larøi, 2006; Larøi \& Woodward, 2007). That is, for example, researchers are using the phenomenological characteristics of hallucinations to either test the validity of previous findings and/or models, and/or have employed a refined phenomenological analysis of the experience or symptom in question in order to guide future research. The study by Hoffman and colleagues (2008) is an excellent example of the merits of adopting both a single-symptom and a phenomenological approach.

Hoffman et al. (2008) ask the question: 'Are schizophrenia patients with auditory-verbal hallucinations

* See Persons (1986) and Costello (1992) for a discussion of the advantages of the single-symptom approach, a critical review of the single-symptom approach by Mojtabai \& Reider (1998), and a reply to this by Bentall (2003).

$\dagger$ Although please note that other symptoms, and most notably (persecutory) delusions, have also attracted researchers' attention. On the other hand, the dominance of positive psychotic symptoms (i.e. hallucinations and delusions) within the single-symptom approach has perhaps been to the detriment of studying other symptoms, such as negative symptoms. Perhaps future research will even out this discrepancy.

\# This revival did not come out of the blue. Certain researchers have for a long time advocated a phenomenological analysis of psychopathological states and experiences (cf. Parnas \& Bovet, 1995; Parnas \& Zahavi, 2002).
(AVHs) able to differentiate between own thoughts and voices and if so, how do they do so?' The results showed that $80 \%$ of patients were able to differentiate AVHs from their usual verbal thoughts either 'most of the time' or 'always'. A similar finding was reported in a recent study (Moritz \& Larøi, 2008) where a large majority of schizophrenia patients expressed being able to distinguish real from hallucinated voices. Although the results from Hoffman et al. (2008) are not entirely clear-cut and seem to suggest considerable individual variability, the results additionally revealed that three characteristics were particularly important in differentiating voices from thoughts: verbal content, degree of control and the non-self 'sound' of the speaking voice.

However, after having read the article, two issues popped into mind. Do the findings have clinical implications? It would have been interesting to match the theoretical reflections with reflections regarding the extent to which the findings might have a clinical impact. Briefly, how do we get patients to gradually come to terms with the fact that their voices are, in reality, internal mental events (i.e. thoughts)? Perhaps it would be fruitful to mention to voice-hearers that thoughts may take a verbal form, are also involuntary or unintended, and may also lead individuals to feel as if they do not belong to oneself. Another issue is that future studies will inevitably need to better elucidate the developmental or dynamic nature of the genesis of hallucinations. To begin with, hallucinations are, ultimately, internal mental events. These internal mental events evolve over time through a complex interaction of cognitive, emotional, biological and socio-cultural mechanisms and factors. They are, as it were, transformed into something else - for some individuals, this transformation results in a voice. Regrettably, we continue to predominantly (although the climate has changed in the past years) study hallucinations when they are fully 'developed' (e.g. hallucinations present in chronic schizophrenia patients). It will be an important future approach to consider when and how internal mental events, such as ordinary everyday thoughts, are transformed into voices. This calls for a developmental approach to hallucinations - yet another approach that researchers will need to include in their toolbox.

\section{Declaration of Interest}

None. 


\section{References}

Aleman A, Larøi F (2008). Hallucinations: The Science of Idiosyncratic Perception. American Psychological Association: Washington, DC.

Bentall RP (2003). Madness Explained: Psychosis and Human Nature. Penguin: London.

Costello CG (1992). Research on symptoms versus research on syndromes: arguments in favour of allocating more research time to the study of symptoms. British Journal of Psychiatry 160, 304-308.

Hoffman RE, Varanko M, Gilmore J, Mishara AL (2008). Experiential features used by patients with schizophrenia to differentiate 'voices' from ordinary verbal thought. Psychological Medicine 38, 1167-1176.

Larøi F (2006). The phenomenological diversity of hallucinations: some theoretical and clinical implications. Psychologica Belgica 46, 163-183.

Larøi F, Woodward T (2007). Hallucinations from a cognitive perspective. Harvard Review of Psychiatry 15, 109-117.

Mojtabai R, Rieder RO (1998). Limitations of the symptom-oriented approach to psychiatric research. British Journal of Psychiatry 173, 198-202.

Moritz S, Larøi F (2008). Differences and similarities in the sensory and cognitive signatures of voice-hearing, intrusions and thoughts. Schizophrenia Research 102, 96-107.

Owen G, Harland R (2007). Theme issue on phenomenology and psychiatry for the 21st century. Taking phenomenology seriously. Schizophrenia Bulletin 33, 105-107.

Parnas J, Bovet P (1995). Research in psychopathology: epistemological issues. Comprehensive Psychiatry 36, 167-181.

Parnas J, Zahavi D (2002). The role of phenomenology in psychiatric classification and diagnosis. In Psychiatric Diagnosis and Classification (ed. M. Maj, W. Gaebel, J. J. López-Ibor and N. Sartorius), pp. 137-162. John Wiley \& Sons: Chichester.

Persons JB (1986). The advantages of studying psychological phenomena rather than psychiatric diagnoses. American Psychologist 41, 1252-1260.

FRANK LARøI

Cognitive Psychopathology Unit,

University of Liège, Boulevard du Rectorat (B33),

4000 Liège, Belgium

(Email: flaroi@ulg.ac.be)

Psychological Medicine, 39 (2009)

doi:10.1017/S0033291708004583

First published online 10 October 2008

\section{Letter to the Editor}

Strong evidence for multiple psychosis susceptibility genes - a rejoinder to Crow

There are many mis-representations of our position in Dr Crow's response (Crow, 2008) to our comment on his paper, but given recent empirical developments in genetic research (Maher et al. 2008), there is little need, and even less time, to engage in a protracted debate on whether there is a genetic basis to psychosis. In the last 2 months, a synthesis of genome-wide data and large sample sets has convincingly shown that common genetic variants, each of weak effect, are indeed involved in schizophrenia (O'Donovan et al. 2008) and bipolar disorder (Ferreria et al. 2008). Moreover, in schizophrenia, there is now consistent and compelling evidence (The International Schizophrenia Consortium, 2008; Stefansson et al. 2008) from molecular genetics for a contribution to risk from copy number variation $(\mathrm{CNV})$, variants that result in the deletion or duplication of 1000 bases or more of DNA sequence. Read with an open mind, these recent papers should change Dr Crow's views.

While we make no argument that epigenetic changes are not involved at all, the molecular data clearly show genetic variation is involved. Moreover, the molecular data clearly point to the involvement in psychosis of multiple regions of the genome, not some single sex-linked part of the genome involved in language and speciation as Dr Crow has long proposed. It must surely now be the time for Dr Crow to reject his own hypothesis of a single cause of psychosis, and to use his well-earned reputation in whatever way he can to enhance the ability of geneticists, and epigeneticists (who are often the same people), to get on with the job of tackling the complexities of psychosis for the benefits of our patients.

\section{Declaration of Interest}

None.

\section{References}

Crow TJ (2008). Will whole genome association studies sink psychosis research? A response to Collier, Sullivan and O'Donovan [Letter]. Psychological Medicine. Published online: 12 August 2008. doi:10.1017/ S0033291708004030.

Ferreira MAR, O'Donovan MC, Meng YA, Jones IR, Ruderfer DM, Jones L, Fan J, Kirov G, Perlis RH, Green EK, Smoller JW, Grozeva D, Stone J, Nikolov I, Chambert K, Hamshere ML, Nimgaonkar V, Moskvina V, Thase ME, Caesar S, Sachs GS, Franklin J, Gordon-Smith K, Ardlie KG, Gabriel SB, Fraser C, Blumenstiel B, Defelice M, Breen G, Gill M, Morris DW, Elkin A, Muir WJ, McGhee KA, Williamson R, MacIntyre DJ, McLean A, St Clair D, VanBeck M, Pereira A, Kandaswamy R, McQuillin A, Collier DA, Bass NJ, Young AH, Lawrence J, Ferrier IN, Anjorin A, Farmer A, Curtis D, Scolnick EM, McGuffin P, Daly MJ, Corvin AP, Holmans PA, Blackwood DH, 